\title{
ALCANCE Y LÍMITES DE LA RESPONSABILIDAD DEL PROPIETARIO POR LOS SUELOS HISTÓRICAMENTE CONTAMINADOS
}

\author{
XABIER ARZOZ SANTISTEBAN ${ }^{\prime}$ \\ Universidad del País Vasco \\ xabier.arzoz@ehu.es
}

Cómo citar/Citation

Arzoz Santisteban, X. (2017).

Alcance y límites de la responsabilidad del propietario por los suelos históricamente contaminados.

Revista de Administración Pública, 204, 69-100.

doi: https://doi.org/10.18042/cepc/rap.204.03

\section{Resumen}

En este trabajo se analiza el alcance de la responsabilidad del propietario actual por el suelo contaminado que él no contribuyó a contaminar y cuya situación no podía conocer en el momento de la adquisición. Se comienza indagando en el alcance y la naturaleza de la obligación legal de descontaminación. A continuación se examina si la normativa contempla o debiera prever límites legales a la citada responsabilidad. En tercer lugar, se analiza la incidencia limitativa o moduladora de las disposiciones constitucionales. El artículo sostiene, por una parte, que la imposición de medidas desproporcionadas de descontaminación no es compatible con el contenido esencial del derecho de propiedad privada y, por otra parte, que en los procesos urbanísticos de equidistribución, la carga de descontaminación debería recaer en quien persiga el nuevo uso urbanístico, esto es, en el promotor de la actuación urbanística.

\section{Palabras clave}

Suelos contaminados; obligación de descontaminación; derecho de propiedad; retroactividad; confianza legítima.

1 Profesor titular de Derecho Administrativo (acred. catedrático). Letrado del Tribunal Constitucional. 


\section{Abstract}

This paper analyses whether there are limitations for proprietors' legal responsibility for remediating polluted soils that they did not contribute to pollute, and of whose polluted situation they were not aware at the time of acquisition. It starts exploring the nature and extent of proprietors' legal duty to remediate soil pollution. Next, it seeks the possibility of deducing or introducing some legal limitations to that duty, either explicitly or implicitly. Then, it moves to the text of the Constitution to search for constitutional guidance. The article argues, first, that the Constitution would not allow for imposing excessive duties of remediation; and, second, that in certain cases the duty of remediation should instead be imposed upon those who will obtain the resulting benefit, for instance, the town planning and property developer, in order to avoid unjust enrichment.

\section{Keywords}

Soil pollution; duty to remediate; property rights; retrospectivity; legitimate expectations. 


\section{SUMARIO}

I. PLANTEAMIENTO. II. LA OBLIGACIÓN LEGAL DE RECUPERAR SUELOS CONTAMINADOS: DEFINICIÓN, ALCANCE Y NATURALEZA. III. LA NATURALEZA OBJETIVA DEL RÉGIMEN DE RESPONSABILIDAD APLICABLE Y SUS CONSECUENCIAS: 1. Naturaleza objetiva del régimen de la responsabilidad aplicable. 2. La improcedencia de exclusiones temporales. 3. La licitud de la actividad contaminante como causa de exoneración. IV. LOS LÍMITES CONSTITUCIONALES: 1. El principio de irretroactividad de las restricciones de los derechos individuales (artículo 9.3 CE). 2. Los principios de seguridad jurídica y de confianza legítima (artículo 9.3 CE). 3. El derecho de propiedad: 3.1. Las medidas de recuperación excesivas. 3.2. La obligación de descontaminación que se yuxtapone a la privación de la propiedad: el caso de los procesos urbanísticos de equidistribución. V. CONCLUSIONES.

\section{PLANTEAMIENTO}

El presente trabajo pretende examinar si existen o deben existir límites a la obligación de los titulares dominicales de limpiar y recuperar los suelos contaminados, centrándose en el problema de las llamadas contaminaciones históricas. Además, lo hará con la mirada puesta en las situaciones en las que el derecho de propiedad sufre un especial «test de estrés». Ello requiere una breve explicación inicial.

Por un lado, se consideran «suelos históricamente contaminados» aquellos que fueron contaminados en épocas anteriores a que la legislación abordara el problema con normas dirigidas a identificar la situación de los suelos y estableciera un régimen de responsabilidad al respecto. Parece claro que quien contamina o tolera la contaminación de un suelo, ya sea como propietario, poseedor o tercero, ha de ser responsable de su recuperación. Nadie discute que quien se beneficia económicamente de la generación de un potencial daño al medio ambiente y, por tanto, al interés general debe responder por ello. Ello contribuye sin duda a que las actividades económicas internalicen el daño al medio ambiente en sus costes de producción. También resulta 
indiscutible que quien, en la actualidad, conoce o debe conocer por la publicidad registral la situación del suelo que adquiere de un tercero y las obligaciones legales que ello supone no puede después alegar válidamente su ausencia de responsabilidad cuando la Administración pública le exija, en aplicación de la ley, que recupere la calidad del suelo.

Ahora bien, ¿qué ocurre en los demás casos: esto es, cuando quienes adquirieron el suelo no sabían - y no podían saber — su situación contaminada ni tampoco la han causado o tolerado? Por lo general, o bien es imposible determinar el causante original de la contaminación del suelo o bien esa persona, física o jurídica, no existe ya. Tampoco cabe invocar los deberes de diligencia y conservación que recaen sobre el propietario: ¿cómo pudo impedir el propietario actual que anteriores propietarios o poseedores o terceros contaminasen el suelo? ¿Debe internalizar dentro de sus costes de producción lo que él no ha generado?

Por otro lado, situaciones típicas de "estrés» para la propiedad privada son los procesos expropiatorios y urbanísticos, en los que se manifiestan con plenitud las obligaciones que dimanan de la función social de la propiedad. La situación de "estrés» se produce en la medida en que el propietario del suelo contaminado se ve confrontado con una actuación urbanística que él no ha buscado, y en la que no quiere o no puede participar (por la importancia de los costes de urbanización previstos, a los que se añaden los de descontaminación), pero que le genera la obligación de recuperar la calidad del suelo o, alternativamente, de sufragar el coste que ello suponga, incluso aunque no sea adjudicatario del suelo resultante de la acción urbanística. A estos efectos la situación es similar a la de quien padece una actuación expropiatoria: la situación del suelo afecta a la formación del justiprecio que le abonará la Administración expropiante o el beneficiario de la expropiación.

La doctrina española viene planteando dudas sobre la extensión de la obligación de recuperar los suelos contaminados en relación con el propietario o poseedor actual que no causó la contaminación ${ }^{2}$. Aunque algunos autores

2 J. M. Baño León (2002), «Los suelos contaminados: obligación de saneamiento y derecho de propiedad», en Revista Aranzadi de Derecho Ambiental, 2, págs. 47-53; I. Sanz Rubiales (2003), «Régimen jurídico administrativo de la restauración de suelos contaminados en el ordenamiento espańol», en Revista de Derecho Urbanístico y Medio Ambiente, 205, págs. 145-183, punto 4 de «Conclusiones»; C. De Miguel Perales (2007), Régimen jurídico español de suelos contaminados, Madrid: Civitas, págs. 109112; I. Pérez Dapena y M. J. Gutiérrez Hernández (2008), «Los supuestos de exención de responsabilidad de los titulares de suelos contaminados. Especial referencia a la legislación del País Vasco», en Revista Vasca de Administración Pública, 81, pág. 368; C. Padrós Reig (2013), «Los suelos históricamente contaminados: comentario 
han explorado los límites a la responsabilidad de los propietarios que prescribe la legislación vigente, las consecuencias que implica la consagración constitucional de un derecho fundamental a la propiedad privada no parecen estar debidamente afianzadas. El objetivo de este trabajo es remediar dicha laguna y contribuir así a configurar un régimen de responsabilidad justo y acorde con los principios y valores constitucionales. La perspectiva será exclusivamente la del ordenamiento jurídico español, si bien se tendrá en cuenta la importante jurisprudencia constitucional alemana sobre los límites de la obligación de saneamiento del propietario por los suelos históricamente contaminados.

\section{LA OBLIGACIÓN LEGAL DE RECUPERAR SUELOS CONTAMINADOS: DEFINICIÓN, ALCANCE Y NATURALEZA}

Hace menos de veinte años que la problemática de los suelos contaminados comenzó a ser abordada en el ordenamiento español. La primera norma española que contempló el problema de los suelos contaminados fue la Ley 10/1998, de 21 de abril, de residuos ${ }^{3}$. Esta ley se ocupó de los suelos contaminados en sus arts. 27 y 28. Pero hasta la aprobación del Real Decreto 9/2005, de 14 de enero, por el que se establece la relación de actividades potencialmente contaminantes del suelo y los criterios y estándares para la declaración de suelos contaminados, no existieron criterios normalizados de valoración de la contaminación del suelo y un mínimo desarrollo normativo del alcance y la ejecución de las obligaciones de recuperación ambiental (art. 7).

La vigente Ley 22/2011, de 28 de julio, de residuos y suelos contaminados (en adelante LRSC) $)^{4}$, que deroga la mencionada Ley 10/1998 y contiene una regulación más amplia, mantiene el mismo modelo de atribución de

de algunas resoluciones jurisprudenciales recientes», en Revista Aranzadi de Derecho Ambiental, 24, págs. 55-80, punto 3; I. Sanz Rubiales y A. de la Varga Pastor (2014), «Regulación, problemática y régimen jurídico de los suelos contaminados», en F. García-Moreno Rodríguez (dir.), Comentarios sistemáticos a la Ley 22/2011, de 28 de julio, de residuos y suelos contaminados, Cizur Menor: Aranzadi, págs. 520-528; M. C. Bolaño Piñeiro (2015), «Responsabilidad en la limpieza y recuperación de los suelos declarados contaminados o alterados en la normativa de suelos contaminados», en Revista de Administración Pública, 196, pág. 363.

3 Véase P. Poveda Gómez (1998), Comentarios a la Ley 10/1998, de 21 de abril, de Residuos, Granada: Comares, 1998; y M. R. Alonso Ibáñez (2002), Suelos contaminados. Prevención y recuperación ambiental, Madrid: Civitas.

4 Al respecto puede verse, en particular, Sanz Rubiales y De la Varga Pastor (2014: 441553). 
responsabilidad: el responsable principal de la restauración de los suelos declarados contaminados será el causante de la contaminación (si fueran varios, responderán solidariamente) y, subsidiariamente, por este orden, responderán los propietarios y los poseedores de los suelos contaminados ${ }^{5}$. Esta reducción de los responsables a tres únicas categorías contrasta, por ejemplo, con la más amplia determinación que prevé la legislación alemana ${ }^{6}$. En la medida en que el poseedor solo sería responsable de forma excepcional, en el raro supuesto de que no se pueda determinar el propietario del suelo, a fin de simplificar la argumentación, dejaremos el supuesto fuera del análisis de este artículo.

La obligación de recuperación de la calidad del suelo tiene carácter jurídico-administrativo. Aunque el deber está previsto en la ley, el surgimiento de la obligación de recuperación requiere de dos actos administrativos sucesivos: primero, la aprobación por el órgano medioambiental competente de la comunidad autónoma de la declaración de la calidad del suelo, que concrete los sujetos responsables, la forma y los plazos de la descontaminación; y, segundo, el requerimiento que impone al responsable la obligación concreta

5 Art. 36.1 LRSC. La principal diferencia en este punto es que, con arreglo a la Ley 10/1998, de 21 de abril, de residuos, los poseedores de los suelos contaminados respondían antes que los propietarios no poseedores de los suelos contaminados. Ahora solo se conserva la preferencia del poseedor, en defecto del causante de la contaminación, en los supuestos de bienes de dominio público en régimen de concesión. También se ha suprimido la extravagante exención de responsabilidad del acreedor que en ejecución forzosa de su crédito deviniera propietario de un suelo contaminado, siempre que lo enajenase en el plazo de un año a partir de la fecha en que accedió a la propiedad (art. 27.4 de la Ley 10/1998).

6 La ley federal alemana de suelos contaminados (Bundes-Bodenschutzgesetz), de 24 de marzo de 1998, prevé en su parágrafo 4.3 las siguientes categorías de responsables: el causante de la alteración del suelo, su sucesor universal, el propietario o poseedor, quien responda por razones mercantiles o societarias de la persona jurídica a la que pertenece el suelo alterado y el derelictor del suelo afectado. La autoridad competente tiene margen de apreciación a la hora de decidir a qué responsable exige la limpieza del suelo, el cual podrá repetir los gastos incurridos contra cualquiera de los demás responsables de acuerdo con lo previsto en el parágrafo. 24.2 de la ley. No obstante, existe unanimidad doctrinal y jurisprudencial de que su decisión debe orientarse según la efectividad de la eliminación de la alteración: véase, en este sentido, W. Finger (2011), «Neues von den Altlasten», Neue Zeitschrift für Verwaltungsrecht, 21, pág. 1289, con más referencias. Este trabajo ofrece una visión panorámica sobre la primera década de aplicación judicial de la ley alemana de suelos contaminados (págs. 1288-1291). Para una introducción en castellano al sistema alemán puede verse también A. de la Varga Pastor (2012), El nuevo régimen jurídico de los suelos contaminados, Madrid: La Ley, págs. 88-91, 114-126, 141-150, 265-295, 327-352, 380-397 y 411-426. 
de hacer ${ }^{7}$. La declaración se limita a constatar la situación del suelo, sin obligar todavía al sujeto responsable y sin surtir efectos frente a terceros: solo el órgano ambiental puede requerir a los sujetos responsables que procedan a la recuperación del suelo, de acuerdo con la declaración de calidad del suelo ${ }^{8}$. La declaración no está desprovista de efectos: por un lado, implica la exclusiva dirección pública del proceso de descontaminación ${ }^{9}$; por otro lado, puede comportar la suspensión de la ejecutividad de los derechos de edificación y otros aprovechamientos del suelo que resulten incompatibles con las medidas de limpieza y recuperación del terreno que se establezcan (art. 34.4 LRSC). El requerimiento previsto por la ley es constitutivo de la obligación individualizada de recuperar el suelo. La Administración no tiene plazo alguno para la emisión del requerimiento ${ }^{10}$. La emisión del requerimiento dependerá de las prioridades de actuación en materia de descontaminación de las comunidades autónomas (art. 35.3 LRSC).

El antes mencionado Real Decreto 9/2005, de 14 de enero, sobre actividades contaminantes del suelo, además de establecer criterios normalizados de valoración de la contaminación del suelo, reguló también la publicidad inmobiliaria ${ }^{11}$. El titular del bien está obligado, con motivo de su transmisión, a declarar en escritura pública que se ha realizado alguna de las actividades potencialmente contaminantes. Ese hecho será objeto de nota marginal en el Registro de la Propiedad (art. 33.2 LRSC). Además, a iniciativa de la respectiva comunidad autónoma, se anotará también en el Registro de la Propiedad la declaración de suelo contaminado (art. 34.3 LRSC). La nota marginal se mantendrá hasta que se acuerde acreditada la descontaminación, si la hubo, o la inexistencia de la causa. Esa publicidad registral tiene trascendencia para las transmisiones y los procesos urbanísticos ${ }^{12}$. Además de la mencionada publicidad inmobiliaria, los suelos declarados contaminados se inscriben también en los inventarios específicos que elaboran las comunidades autónomas, a partir de cuya información se elabora el inventario estatal de suelos contaminados (art. 35 LRSC).

\footnotetext{
Sanz Rubiales y De la Varga Pastor (2014: 485-488).

Bolaño Piñeiro (2015: 341).

Sanz Rubiales y De la Varga Pastor (2014: 497).

Sanz Rubiales y De la Varga Pastor (2014: 486).

11 El Real Decreto 9/2005, dictado en desarrollo de la Ley 10/1998, se mantiene en vigor como desarrollo reglamentario de la Ley 22/2011.

12 Al respecto puede verse J. L. Laso Martínez (2007), «Consecuencias registrales de las medidas medioambientales en materia de suelos potencialmente contaminados y sus implicaciones en los procesos urbanísticos de equidistribución», en Revista Crítica de Derecho Inmobiliario, 703, págs. 2359-2367.
} 
Finalmente, conviene referirse a la articulación de la obligación de descontaminación en los procesos urbanísticos, que a menudo consisten justamente en la reutilización de suelos contaminados. En principio, un emplazamiento en el que se ha desarrollado una actividad industrial potencialmente contaminante del suelo no supone necesariamente un problema de riesgo para el medio ambiente o la salud de las personas: el riesgo para el medio ambiente o la salud de las personas, así como la oportunidad de saneamiento, suelen aparecer si el uso urbanístico del suelo sufre una modificación ${ }^{13}$. En suma, uno de los supuestos típicos en los que se exige la ejecución de la obligación de descontaminación es cuando el suelo ha de ser objeto de una actuación urbanística. Teniendo presente esta circunstancia, el régimen jurídico del saneamiento de los suelos contaminados no debería contemplarse exclusivamente desde el derecho ambiental, sino también desde el derecho urbanístico ${ }^{14}$. No obstante, la perspectiva del derecho urbanístico es todavía discreta en este ámbito, quizás en la consideración de que la normativa urbanística autonómica no puede sustituir a la normativa básica ambiental en la determinación de los responsables de la descontaminación del suelo ${ }^{15}$. Ello explica que la descontaminación del suelo se considere un gasto de urbanización especial, que se impone como carga individualizada a los propietarios del suelo contaminado y no al conjunto de la comunidad reparcelatoria, sin perjuicio de la facultad de aquellos de repercutir el coste al causante de la contaminación ${ }^{16}$.

El establecimiento legal de la obligación de descontaminación constituye una delimitación del contenido del derecho de propiedad, en el que se incluye la función social que dicho derecho debe cumplir (art. 33.2 CE) ${ }^{17}$. En otras palabras, responde a la capacidad del legislador de definir la función social de

13 J. A. Loste Madoz (2007), «Desarrollo autonómico del R. D. 9/2005 sobre suelos contaminados: límites de la prestación de remediación del suelo contaminado», en Revista de Derecho Urbanistico y Medio Ambiente, 235, pág. 158.

14 Loste Madoz (2007: 158).

15 J. A. Loste Madoz (2011), «Contribución al borrador de Ley de Residuos y Suelos Contaminados», Diario La Ley, 7575, sección Tribuna, 23 Feb. 2011, XXXII, ref. D-84.

16 Así, el art. 127.3 del Reglamento de la Ley de Urbanismo de Cataluña, aprobado por Decreto 305/2006, de 18 de julio, o el art. 147.3 de la Ley 2/2006, de 30 de junio, del suelo y urbanismo del País Vasco. Al respecto de la última norma puede consultarse I. Pérez Dapena y E. Picó Barandiarán (2011), «Gestión urbanística de los suelos contaminados en el País Vasco: la obligación de recuperar suelos contaminados en los procesos de equidistribución", en Revista de Derecho Urbanistico y Medio Ambiente, 270, págs. 113-134.

17 Para A. M. López y López (1988), La disciplina constitucional de la propiedad privada, Madrid: Tecnos, pág. 70, la función social es «el único criterio con eficacia delimita- 
un tipo concreto de propiedad (la propiedad sobre el suelo) de acuerdo con su situación ambiental: la función social consiste justamente en el deber, que se impone al propietario, de recuperar la calidad del suelo que ha sufrido un proceso de alteración, aunque no sea el causante de la contaminación. Por tanto, se trata de una variante más de delimitación del contenido del derecho de propiedad en relación con un tipo de bienes, que atiende a la situación del suelo y a sus perjuicios para el medio ambiente y la salud de las personas, y que se añade a otras delimitaciones del contenido del derecho de propiedad con una justificación ambiental, como, por ejemplo, aquellas que buscan la conservación de los espacios naturales y las especies a proteger y que pueden llegar incluso a la prohibición de determinadas actividades económicas en un espacio natural (extractivas de mineral y cualesquiera incompatible con las finalidades que justifiquen la creación de la concreta modalidad de protección del espacio natural $)^{18}$. Como delimitación del contenido del derecho de propiedad, la obligación de descontaminación tampoco está exenta de límites constitucionales, como veremos en el apdo. IV de este artículo ${ }^{19}$. Antes de examinar los límites constitucionales, debemos detenernos en el régimen legal de la propia obligación de descontaminación e indagar en la posible existencia de límites legales en su aplicación.

\section{LA NATURALEZA OBJETIVA DEL RÉGIMEN DE RESPONSABILIDAD APLICABLE Y SUS CONSECUENCIAS}

\section{NATURALEZA OBJETIVA DEL RÉGIMEN DE LA RESPONSABILIDAD APLICABLE}

Tanto la anterior Ley 10/1998 como la vigente Ley 22/2011 determinan quiénes serán los sujetos responsables, pero no precisan el sistema de

dora del contenido normal de la propiedad por razones de interés general que conoce nuestro ordenamiento».

18 STC 170/1989, de 19 de octubre, FJ 8.

$19 \mathrm{Y}$ aun de límites jurídico-internacionales y jurídico-supranacionales, de los que no podemos ocuparnos en el limitado espacio del presente artículo, como son las prescripciones normativas contenidas en el sistema del Convenio Europeo de Derechos Humanos (art. 1 del protocolo adicional núm. 1) y en el derecho de la Unión (art. 17 de la Carta de Derechos Fundamentales). Al respecto puede verse D. Utrilla Fernández-Bermejo (2011), Las garantías del derecho de propiedad privada en Europa, Cizur Menor: Civitas-Thomson Reuters, y J. Barcelona Llop (2013), Propiedad, privación de la propiedad y expropiación forzosa en el sistema del Convenio Europeo de Derechos Humanos, Madrid: CEPC. 
responsabilidad que se aplica, si se trata de un sistema objetivo o subjetivo. Al no especificarse otra cosa, del contenido de la regulación se deduce la opción por un sistema objetivo de responsabilidad.

El régimen que instaura la Ley presenta una doble dificultad conceptual. En primer lugar, la expresión «responsabilidad» puede ser equívoca ${ }^{20}$ : no se trata de la tradicional responsabilidad civil extracontractual por daños en los bienes y derechos de las personas ${ }^{21}$, sino de un sistema jurídico-público ${ }^{22}$ que busca la identificación y la restauración del suelo contaminado, como situación objetiva de riesgo, con la finalidad de prevenir daños a la salud humana y al ecosistema ${ }^{23}$. En segundo lugar, como fue puesto de relieve en un temprano análisis doctrinal, en la regulación legal se mezclan dos tipos de responsabilidad sustancialmente diferentes: una personal, por conducta, y otra real, como consecuencia de un derecho patrimonial sobre la $\operatorname{cosa}^{24}$. En el primer título de imputación sí que hay amplia coincidencia con la responsabilidad civil extracontractual, pues también requiere como elemento esencial el nexo causal entre la conducta del supuesto responsable y el daño causado. Esta dualidad de títulos de imputación se sujeta, no obstante, a un mismo régimen legal,

$20 \mathrm{El}$ art. 36 LRSC habla de «sujetos responsables de la descontaminación», «obligados a realizar las operaciones de descontaminación y recuperación», «responsables subsidiarios».

21 Los dańos a bienes y derechos privados se reclaman mediante la responsabilidad civil general. Si interviene el derecho público es porque hay «daños públicos ambientales». Como señalan Sanz Rubiales y De la Varga Pastor (2014: 504), la obligación de restaurar los suelos contaminados encuadra mejor «en el principio de prevención (o, en su caso, de precaución) que en el de corrección"; se trata de prevenir la extensión de la contaminación a otros recursos naturales, a la biodiversidad o a la salud humana, esto es, a valores e intereses que no son privativos del propietario o poseedor. Por la misma razón, la obligación de restaurar el suelo se modula en función de su uso: si la situación del suelo es aceptable para el uso al que se destina (por ejemplo, uso industrial), la legislación no le obliga al propietario a más.

B. Lozano Cutanda (2005), «La responsabilidad por daños ambientales: la situación actual y el nuevo sistema de "responsabilidad de derecho público" que introduce la Directiva 2004/35/CE», en Justicia administrativa, 26, págs. 5-33.

23 En el mismo sentido Alonso Ibáńez (2002: 210). Por ello, no parece del todo correcta la equiparación con diversos supuestos, previstos en el Código Civil, de responsabilidad directa o subsidiaria del propietario o poseedor (arts. 1905 y 1910 CC) que realiza N. Álvarez Lata (2016), «La obligación del propietario no contaminador de reparar los terrenos contaminados. La regulación del derecho español a propósito de la STJUE (Sala 3a), de 4 de marzo de 2015, asunto C-534/13», en Revista General de Derecho Europeo, 39, pág. 9.

Baño León (2002: 46). 
cuya uniformidad hace tabla rasa de las enormes diferencias que subyacen a ambos títulos de imputación..$^{25}$ Solo caracterizando y diferenciando adecuadamente esos títulos de imputación podrán alcanzarse conclusiones válidas para la interpretación, la aplicación y el desarrollo de las normas legales.

Uno de los problemas planteados por la legislación básica sobre suelos contaminados ha sido el de su relación con la legislación, también básica, sobre responsabilidad ambiental (Ley 26/2007, de 23 de octubre) ${ }^{26}$, que presenta muchas diferencias con respecto a aquella ${ }^{27}$. Por ejemplo, la Ley 26/2007 establece una responsabilidad medioambiental objetiva en relación con las actividades recogidas en su anexo III y una responsabilidad subjetiva para las demás actividades: los operadores que, realizando actividades distintas de las recogidas en su anexo III, produzcan daños al medio ambiente solo responderán mediando dolo, culpa o negligencia ${ }^{28}$. Una primera duda era si esa dualidad de responsabilidad objetiva (regla general para las actividades potencialmente contaminantes) y subjetiva (excepción aplicable a las demás actividades) que recoge la Ley 26/2007 derogaba el régimen previsto en la legislación sobre suelos contaminados; y, en caso afirmativo, si solo se proyectaba sobre los causantes de la contaminación o también sobre los responsables subsidiarios. Si el propio causante de la contaminación solo responde, cuando sus actividades no están enumeradas en la Ley, mediando dolo, culpa o negligencia, ¿por qué habría de responder por los efectos de esas mismas

25 Piénsese, por ejemplo, en el alcance de la responsabilidad y en la imprescriptibilidad de la acción pública. La responsabilidad por conducta debe ser íntegra, incluyendo la plena restauración del suelo contaminado, aunque sujeta a plazo. En cambio, la responsabilidad por la condición de propietario se basa en la situación de riesgo, e incluye la descontaminación hasta niveles aceptables para la salud humana y el medio ambiente, y no debe sujetarse a plazo.

26 Véase B. Lozano Cutanda (coord.) (2008), Comentarios a la Ley de responsabilidad medioambiental: Ley 26/2007, de 23 de octubre, Cizur Menor: Thomson-Civitas.

27 Diferencias en cuanto a los sujetos responsables, el alcance y el régimen de la responsabilidad aplicable, las causas de exoneración de la responsabilidad, el carácter retroactivo de sus normas y los plazos para exigir la responsabilidad. $\mathrm{Al}$ respecto puede verse también F. Gómez Pomar y M. Gili Saldaña (2006), «Responsabilidad por daños al medio ambiente y por contaminación de suelos: problemas de relación», en Indret. Revista para el Análisis del Derecho, 337; también puede consultarse A. de la Varga Pastor (2009), «La coordinación entre la Ley 10/1998 de residuos y la Ley 26/2007 de responsabilidad medioambiental en materia de suelos contaminados», en Revista Vasca de Administración Pública, 84, págs. 233-260.

28 Art. 3, apartados 1 y 2, de la Ley 26/2007. Para Bolaño Piñeiro (2015: 363), esta diferenciación no es acertada. 
actividades el propietario actual si no hay nexo causal entre su actividad y la contaminación existente en el suelo?

Hoy parece claro que el régimen de la legislación sobre suelos contaminados prevalece sobre el de la de responsabilidad ambiental. No solo porque la vigente Ley 22/2011 es posterior en el tiempo a la Ley 26/2007, o porque esta no derogó a la Ley 10/1998, o porque la Ley 22/2011 contenga un régimen de responsabilidad más riguroso que esta (lo cual viene permitido por la Directiva 2004/35/CE), sino porque se trata de una ley especial, que aborda la situación de los suelos contaminados desde una perspectiva específica: concibe la responsabilidad del propietario como una responsabilidad autónoma fundamentada en la definición de la función social de la propiedad. Por ello, va más allá del principio "quien contamina paga»" ${ }^{29}$, lo que se comprueba en su aplicabilidad tanto a la contaminación histórica como a la difusa. Dada la especialidad y autonomía de la legislación básica sobre suelos contaminados se comprende que la responsabilidad subsidiaria del propietario deba ser objetiva, esto es, que no exija una relación entre el daño y su autor ${ }^{30}$.

\section{LA IMPROCEDENCIA DE EXCLUSIONES TEMPORALES}

La legislación básica sobre suelos contaminados nada dispone sobre eventuales límites temporales de la responsabilidad que establece. En cambio, la legislación básica sobre responsabilidad ambiental limita el efecto retroactivo de la norma a treinta años desde que tuvo lugar el suceso causante del dańo, plazo que se computará desde el día en que haya terminado por completo la contaminación o se haya producido por última vez la emisión, el suceso o el incidente de que se trate ${ }^{31}$. Por tanto, si se aplicara el citado criterio temporal, el causante de la contaminación del suelo no respondería hoy por las contaminaciones históricas finalizadas por completo antes de 1987; en consecuencia, podría entenderse quizá que tampoco debería responder el actual propietario del suelo.

Por su parte, Baño León propone una interpretación que también limita el alcance de la obligación de descontaminación. Sostiene que la retroactividad de la Ley básica de residuos de 1998 (el argumento valdría también para las posteriores leyes básicas) solo podría afectar a las actuaciones contaminantes que se hayan iniciado o desarrollado después de la entrada en vigor de la Constitución de 1978, porque solo desde entonces rige el art. $45 \mathrm{CE}^{32}$.

29 Gómez Pomar y Gili Saldaña (2006: 13).

30 Sanz Rubiales (2003); Sanz Rubiales y De la Varga Pastor (2014: 522).

31 Art. 4 de la Ley 26/2007.

32 Baño León (2002: 51). Este criterio es compartido por M. C. Bolaño Piñeiro (2014), «La aplicación retroactiva de las Leyes 22/2011 y 1/2005, en referencia a la obligación 
La legislación vasca ha planteado asimismo un tratamiento diferenciado de las contaminaciones históricas: atiende al momento en que se produjo la contaminación para modular el alcance de la responsabilidad. Siguiendo la estela de una ley anterior (la Ley 1/2005), la Ley vasca 4/2015, de 25 de junio, para la prevención y corrección de la contaminación del suelo distingue entre la acción contaminante realizada antes de $1998^{33}$ y la realizada con posterioridad. Con respecto a la primera, las medidas de recuperación de un suelo declarado contaminado tendrán como finalidad «devolver al mismo su capacidad para desempeñar las funciones propias del uso al que esté o vaya a estar destinado, utilizando la mejor tecnología disponible». En cambio, cuando la acción contaminante haya tenido lugar con posterioridad a dicha fecha, las medidas de recuperación tendrán como finalidad «restablecerlo a su estado anterior, o, si no fuera conocido, alcanzar unos estándares de calidad» que se precisan en la propia norma.

En mi opinión, la fijación de límites temporales casa mejor con un sistema de responsabilidad por conducta que con un sistema de obligaciones por la condición de propietario. Obligar a alguien a limpiar y recuperar el suelo que contaminó hace décadas, en el caso de que fuera materialmente posible, puede considerarse desproporcionado pues hace tiempo que dejó de obtener beneficio por esa actividad. Por eso, resulta razonable acotar temporalmente el supuesto de hecho de la actividad contaminante que origina el deber de reparar por la conducta propia. Así, la Ley 26/2007 establece treinta años desde la finalización de actividad contaminante. En cambio, las obligaciones del propietario actual se deben contemplar desde otra perspectiva. El propietario ostenta una posición de garante de la situación de su suelo, por lo que debe velar por que la calidad de ese suelo sea tal que no comporte un riego inaceptable para la salud humana y el medio ambiente ${ }^{34}$, con independencia de quién y cuándo lo contaminó. La imposición de una obligación preventiva de saneamiento se justifica, como vimos, en la función social de la propiedad.

de recuperar los suelos declarados contaminados o alterados en la comunidad autónoma del País Vasco», en Revista Aranzadi de Derecho Ambiental, 28, págs. 223-249.

Más exactamente, antes de la entrada en vigor de la Ley 3/1998, de 27 de febrero, general de protección del medio ambiente del País Vasco, que es la primera norma legal vasca que regula los suelos contaminados (arts. 80 a 84): esto es, antes del 27 de junio de 1998. La fecha coincide aproximadamente con la entrada en vigor -12 de mayo de 1998 - de la primera norma estatal — Ley 10/1998, de 21 de abril, de residuosque dispuso las obligaciones de recuperar la calidad del suelo.

Sanz Rubiales y De la Varga Pastor (2014: 522). 


\section{LA LICITUD DE LA ACTIVIDAD CONTAMINANTE COMO CAUSA DE EXONERACIÓN}

La legislación vasca exime de responsabilidad al propietario en los supuestos de ausencia de culpa o negligencia y, cumulativamente, actuación realizada conforme a las condiciones de autorización ${ }^{35}$. En la misma línea, algunos autores han defendido de lege ferenda la exención de responsabilidad cuando la contaminación histórica trae causa de una actividad lícita, esto es, cuando la actividad que causó la contaminación del suelo en el pasado contaba con todas las autorizaciones legales pertinentes ${ }^{36}$. Sin embargo, la legislación estatal guarda silencio a este respecto. De hecho, una sentencia de la Sala de lo Civil del Tribunal Supremo rechaza la licitud de la actividad contaminante como causa de exoneración de la responsabilidad que se impone a los causantes de la contaminación ${ }^{37}$.

Sin duda, la acreditación de la licitud de la actividad contaminante del suelo suscitaría dificultades prácticas en las contaminaciones que no tienen una causa clara, esto es, en las llamadas contaminaciones históricas y difusas, salvo que se estableciera una presunción iuris tantum de licitud de la actividad o actividades contaminantes que afectaron al suelo. En efecto, si ya resulta difícil identificar y desagregar todas y cada una de las actividades potencialmente contaminantes desarrolladas con anterioridad en la misma ubicación o en su entorno, ¿cómo acreditar también si contaron o no con la debida licencia o autorización administrativa y, en su caso, en qué términos fue otorgada? ¿Hasta dónde habría que retrotraerse? Con todo, el principal problema de la aceptación de la licitud de la actividad contaminante como causa de exoneración es su justificación: el propietario actual no sería responsable si el titular de la actividad contaminante hubiera operado de forma lícita y sí, en cambio, si aquel no hubiera actuado de forma lícita. La diferenciación resultante no resulta convincente: en ambos casos el propietario actual no tuvo que ver con

35 Véase el art. 43.4 de la Ley vasca 4/2015, de 25 de junio, para la prevención y corrección de la contaminación del suelo. A ello se ańade una causa de exención por los llamados «riesgos del desarrollo» (emisiones o actividades que «se demuestre que no se habían considerado potencialmente perjudiciales para el suelo según el estado de los conocimientos científicos y técnicos existentes en el momento en que se produjo la emisión o tuvo lugar la actividad) y otra causa de exención por la concurrencia de causas naturales no imputables a la acción humana».

36 Loste Madoz (2007): 153; Pérez Dapena y Gutiérrez Hernández (2008: 371).

37 Sentencia de la Sala de lo Civil del Tribunal Supremo, Sección Primera, de 10 de octubre de 2016 (núm. 616/2016, ponente: F. Pantaleón Prieto, RJ1201614947). 
esa contaminación. La falta de antijuridicidad en la conducta del titular de la actividad le exime de responsabilidad sancionadora, pero no de reparar las consecuencias lesivas de su conducta, salvo que fueran resultado de una orden u obligación impuesta por los poderes públicos. Y si hubiera que diferenciar, habría de ser en sentido inverso, pues si hubo una actividad contaminante ilícita en el pasado, ¿no habría de ser (co-)responsable en alguna medida la Administración pública que no ejerció debidamente sus competencias? En mi opinión, el criterio de la licitud de la actividad contaminante podría ser adecuado para delimitar el alcance de la responsabilidad personal del causante de la contaminación ${ }^{38}$ y fundamentar, en su caso, la responsabilidad patrimonial concurrente de la Administración pública competente ${ }^{39}$. Sin embargo, la responsabilidad del propietario actual se mueve en otro plano: el de la situación de riesgo que resulta de la contaminación del suelo de su propiedad.

\section{LOS LÍMITES CONSTITUCIONALES}

\section{EL PRINCIPIO DE IRRETROACTIVIDAD DE LAS RESTRICCIONES DE LOS DERECHOS INDIVIDUALES (ARTÍCULO $9.3 \mathrm{CE}$ )}

El primer problema interpretativo que suscita el régimen de responsabilidad de los propietarios por suelos históricamente contaminados es si resulta aplicable a la contaminación que trae causa de actividades o emisiones realizadas antes de la entrada en vigor de la primera ley estatal que abordó la cuestión y, en caso afirmativo, ello es compatible con los principios y valores constitucionales.

Al igual que su predecesora (la Ley 10/1998, de 21 de abril, de residuos), la vigente legislación básica en materia de suelos contaminados (Ley 22/2011) guarda silencio sobre este punto. No obstante, a la vista de que la declaración de suelo contaminado versa sobre una situación que trae causa del pasado, diversos autores han concluido que se trata de una Ley potencialmente retroactiva ${ }^{40}$. De hecho, inicialmente la doctrina mostró su inquietud sobre el carácter retroactivo

38 Compárese a este respecto el art. 14.2 de la Ley 26/2007.

39 En este mismo sentido, Pérez Dapena y Gutiérrez Hernández (2008: 374); Padrós Reig (2013: punto 2.2); Loste Madoz (2015: 917).

40 Baño León (2002: 49-53); Gómez Pomar y Gili Saldaña (2006: 26); Bolaño Piñeiro (2014). 
de la Ley de residuos, desde la perspectiva de los principios de seguridad jurídica y confianza legítima ${ }^{41}$.

Además, conviene recordar que algunas interpretaciones doctrinales y ciertas disposiciones legales, antes aludidas, procuran acotar temporalmente el supuesto de hecho para el que rige la responsabilidad por la situación del suelo y, con diversas técnicas, la circunscriben a la contaminación causada en el pasado más cercano: ya sea mediante el plazo preclusivo de treinta años que fija la no retroactiva Ley de responsabilidad ambiental de 2007, ya sea mediante la afirmación doctrinal de una especie de dies a quo, que puede ser la entrada en vigor de la Constitución como inicio de la eficacia del art. $45 \mathrm{CE}$ o la fecha de 1998 como año en el que se introducen las primeras previsiones legales al respecto ${ }^{42}$.

Ahora bien, cabe preguntarse si, incluso con respecto a la contaminación causada en ese marco temporal acotado, la imposición de una responsabilidad subsidiaria al propietario tiene carácter retroactivo y, en caso afirmativo, si esa retroactividad está aceptada o prohibida por la Constitución. La cuestión es clave, pues podría determinar una radical imposibilidad de configurar un título de imputación válido de responsabilidad vinculado a la propiedad por las llamadas contaminaciones históricas.

La Constitución no conoce una prohibición general de leyes o normas retroactivas, sino solo prohibiciones específicas. Los arts. 25 y $9.3 \mathrm{CE}$ solo prohíben la retroactividad de las disposiciones penales y sancionadoras no favorables y de las restrictivas de derechos individuales. Las normas que regulan la responsabilidad subsidiaria del propietario del suelo contaminado no tienen carácter penal ni sancionador. Las dudas se plantean con respecto al otro tipo de retroactividad prohibida por el art. 9.3 CE, en cuanto que el derecho de propiedad sí encaja en la noción de derecho individual reconocido en la Constitución (art. 33) ${ }^{43}$. Para algunos autores, la norma legal que le

41 Alonso Ibáñez (2002: 205); Sanz Rubiales (2003: puntos 3.3.3 y 4); Bolaño Piñeiro (2014), en la consideración que realiza al final de su artículo.

42 Un criterio similar acoge, de lege lata, la legislación alemana, como se indica posteriormente en el texto, en función de la entrada en vigor de la Ley Federal de protección del suelo, en 1999.

43 Es reiterada la jurisprudencia constitucional según la cual, la expresión «restricción de derechos individuales» del art. 9.3 CE «ha de equipararse a la idea de sanción», por lo que hay que considerar que el límite de dicho artículo «se refiere a las limitaciones introducidas en el ámbito de los derechos fundamentales y de las libertades públicas (del título I de la Constitución) o en la esfera general de protección de la persona» (SSTC 42/1986, de 10 de abril, FJ 3, 104/2000, de 13 de abril, FJ 6; 131/2001, de 7 de junio, FJ 5; 112/2006, de 5 de abril, FJ 17; 89/2009, de 20 de abril, FJ 4; 90/2009, 
impone al propietario actual la obligación de descontaminación no incurre en la irretroactividad prohibida del art. 9.3 CE porque no restringe el derecho de propiedad más allá de los límites justificados por su función social ${ }^{44}$. Este razonamiento desconoce la autonomía del principio constitucional de irretroactividad y confunde dos límites constitucionales distintos que se proyectan sobre el legislador — los de los arts. 9.3 y 53.1 CE—: una norma no deja de ser retroactiva por no afectar al contenido esencial.

Baño León aprecia en este ámbito una alteración del contenido del derecho de propiedad con efecto retroactivo, vedado por la Constitución. Fundamenta su conclusión en tres tipos de argumentos. En primer lugar, señala que «conceptualmente, el grado de retroactividad es mucho mayor en el supuesto del propietario o del poseedor que en el del causante de la contaminación». Esto es, atiende al diferente título de imputación de la responsabilidad: «La del propietario es una responsabilidad objetiva conexa al dominio sobre la cosa». En segundo lugar, contrapone las limitaciones o cargas generales con las que el legislador puede gravar la propiedad con «la obligación individual a partir de la adquisición de la propiedad por el hecho anterior de otro». Finalmente, arguye que «resulta a todas luces excesivamente oneroso y contrario al más elemental sentido de la seguridad jurídica» «exigir a quien adquirió antes de la promulgación de la obligación legal de saneamiento que responda a su costa de la conducta de un tercero» ${ }^{45}$.

En mi opinión, la norma estatal que impone la responsabilidad del propietario (art. 36 LRSC) no constituye un supuesto de retroactividad: no se aplica a situaciones de hecho producidas con anterioridad y ya consumadas, ni a los efectos pretéritos de situaciones de hecho producidas con anterioridad pero aún no consumadas y agotadas, sino a los efectos presentes y futuros de situaciones de hecho nacidas con anterioridad pero aún no consumadas o agotadas (en cuanto que persiste la situación de contaminación causada en el pasado). Sin duda, el supuesto de hecho normativo está conectado con un fenómeno contaminante que pudo tener lugar enteramente en el pasado, pero la Ley no se aplica a los efectos producidos en el pasado, sino a los que se producen con posterioridad a su entrada en vigor. En suma, atendiendo

de 20 de abril, FJ 4; y 100/2012, de 8 de mayo, FJ 10; y 216/2015, de 22 de octubre, FJ 7). Diversos autores han defendido una interpretación más restrictiva de la noción de «derechos individuales» en el sentido del art. 9.3 CE: F. López Menudo (1982), El principio de irretroactividad en las normas jurídico-administrativas, Sevilla: Instituto García Oviedo, págs. 216-228; M. Azpitarte Sánchez (2008), Cambiar el pasado, Madrid: Tecnos, pág. 131.

45 Baño León (2002: 52). 
al criterio de que solo son leyes retroactivas las que extienden sus efectos a un periodo pretérito ${ }^{46}$, debe descartarse el carácter retroactivo de las normas aplicables a los suelos contaminados. La obligación de descontaminación sería retroactiva si recayera en quien era el propietario del suelo en el momento en que se produjo la contaminación, aunque no lo fuera en el momento actual. Los argumentos que aduce Baño León no enervan, a mi juicio, la conclusión anterior. Al calificar como "subsidiaria» la responsabilidad del propietario, se genera la impresión de que el propietario deriva su responsabilidad del mismo hecho imputado al responsable principal (el causante de la contaminación), un hecho que puede haberse producido con anterioridad a la entrada en vigor de la Ley 10/1998. Con independencia de la calidad jurídico-técnica del diseño legal establecido, el título de imputación del propietario no es la conducta de un tercero, sino la titularidad actual de un derecho real, y ello obliga a considerar de forma autónoma sus presupuestos lógicos ${ }^{47}$.

\section{LOS PRINCIPIOS DE SEGURIDAD JURÍDICA Y DE CONFIANZA LEGÍTIMA (ARTÍCULO 9.3 CE)}

La exclusión de la aplicación del principio de irretroactividad de las disposiciones restrictivas de derechos individuales no impide el juego de otros principios constitucionales. La jurisprudencia constitucional considera que

46 En la doctrina véase F. López Menudo (1991), «El principio de irretroactividad de las normas en la jurisprudencia constitucional», en S. Martín-Retortillo Baquer (coord.), Estudios sobre la Constitución Española - Homenaje al profesor Eduardo García de Enterría, vol. I, Madrid: Civitas, pág. 501; J. García Luengo (2002), El principio de protección de la confianza en el derecho administrativo, Madrid: Civitas, pág. 219; M. Bacigalupo Sagesse (2002), «Límites constitucionales a la innovación legislativa: retroactividad, retrospección y responsabilidad patrimonial del Estado», en Documentación Administrativa, 263-264, pág. 116; J. M. Baño León (2016), "Cave legislatorem. Confianza en el legislador e interés general», en VV.AA., Riesgo regulatorio en las energías renovables II, Cizur Menor: Aranzadi, pág. 83. Este criterio estricto ha sido seguido también por la jurisprudencia constitucional española, véase STC 42/1986, de 10 de abril, FJ 3: «Lo que se prohíbe en el art. 9.3 es la retroactividad, entendida como incidencia de la nueva Ley en los efectos jurídicos ya producidos de situaciones anteriores»; en el mismo sentido, SSTC 108/1986, FJ 17; 65/1987, FJ 19; 99/1987, FJ 6 b); 112/2006, de 5 de abril, FJ 17; y 216/2015, de 22 de octubre, FJ 7. Así lo señaló ya López Menudo (1991: 500).

47 La interpretación que se realiza en el texto es compatible con los criterios que manifiesta la Sentencia de la Sala de lo Civil del Tribunal Supremo, Sección Primera, de 10 de octubre de 2016 (núm. 616/2016, Ponente: F. Pantaleón Prieto, RJ1201614947) y que descarta que la aplicación al caso del art. 27.2 de la Ley 10/1998 vulnerase la presunción de irretroactividad de las leyes establecida en el art. 2.3 CC. 
los principios de seguridad jurídica y de confianza legítima se proyectan también sobre las medidas retroactivas no prohibidas por los arts. 9.3 y $25.1 \mathrm{CE}$ $\mathrm{e}$, incluso, sobre las modificaciones legislativas con eficacia inmediata ${ }^{48}$. Ahora bien, esos principios no tienen un valor absoluto. En la reciente serie de sentencias relativas al recorte de las primas a la producción eléctrica, el Tribunal Constitucional ha reiterado de nuevo su doctrina tradicional: «Los principios de seguridad jurídica y su corolario, el de confianza legítima, no suponen el derecho de los actores económicos a la permanencia de la regulación existente en un momento dado en un determinado sector de actividad. Dicha estabilidad regulatoria es compatible con cambios legislativos, cuando sean previsibles y derivados de exigencias claras del interés general ${ }^{\star 4}$. Para enjuiciar la posible inconstitucionalidad de los cambios legislativos, la jurisprudencia constitucional atiende a las circunstancias específicas que concurran en cada caso y al grado de retroactividad de la norma cuestionada. En particular, distingue entre aquellas disposiciones legales que con posterioridad pretenden anudar efectos a situaciones de hecho producidas o desarrolladas con anterioridad a la propia Ley y las que pretenden incidir sobre situaciones o relaciones jurídicas actuales aún no concluidas: «En el primer supuesto — retroactividad auténtica-, la prohibición de la retroactividad operaría plenamente y solo exigencias cualificadas del bien común podrían imponerse excepcionalmente a tal principio; en el segundo - retroactividad impropia_, la licitud o ilicitud de la disposición resultaría de una ponderación de bienes llevada a cabo caso por caso teniendo en cuenta, de una parte, la seguridad jurídica y, de

48 Diversos autores no comparten el planteamiento del Tribunal Constitucional formulado a imitación de su homólogo alemán y consideran que los límites de la potestad legislativa derivados del principio de seguridad jurídica ya fueron considerados exhaustivamente por el constituyente al formular el art. 9.3 CE, y que otros límites al carácter retroactivo de una normativa solo pueden buscarse en la elaboración de una dogmática de los derechos fundamentales. Vease en este sentido García Luengo (2002: 224), en línea de principio; y Azpitarte Sánchez (2008: 129-131), con propuestas concretas y argumentadas a partir del principio democrático. En contra, Bacigalupo Saggese (2002: 125, 128-130), sobre la base de la inexistencia de alternativas serias al principio de protección de la confianza; y Baño León (2016). Una reflexión general sobre regulación y confianza ofrece S. Muñoz Machado (2016): «Regulación y confianza legítima», en Revista de Administración Pública, 200, págs. 141-172.

49 STC 270/2015, de 20 de octubre, FJ 7. Doctrina aplicada en las SSTC 19/2016, de 4 de febrero; 29/2016, de 18 de febrero; 30/2016, de 18 de febrero; 42/2016, de 3 de marzo, y 61/2016, de 17 de marzo, por las que se resuelven distintos recursos presentados contra los mismos preceptos del Real Decreto Ley 9/2013, por el que se adoptan medidas urgentes para garantizar la estabilidad financiera del sistema eléctrico. 
otra, los diversos imperativos que pueden conducir a una modificación del ordenamiento jurídico-tributario, así como las circunstancias concretas que concurren en el caso" ${ }^{50}$.

En otras palabras, la eficacia protectora del principio de seguridad jurídica es mayor en los supuestos de retroactividad auténtica y menor en los supuestos de retroactividad impropia. La jurisprudencia constitucional es menos reticente a aceptar la imprevisibilidad con respecto a las medidas de carácter retroactivo ${ }^{51}$. Aunque deja la puerta abierta a una posible vulneración de los principios de seguridad jurídica y confianza legítima en casos de modificaciones legislativas «absolutamente imprevisibles" ${ }^{52}$, el Tribunal Constitucional no suele apreciar la nota de imprevisibilidad en las medidas que entran en vigor de forma inmediata, aunque tengan un alto impacto económico para los afectados, como los recortes de las retribuciones de los funcionarios públicos ${ }^{53}$ y de las primas a la producción eléctrica ${ }^{54}$.

Una vez apuntadas las claves de la jurisprudencia constitucional en la materia, se puede abordar el supuesto de hecho objeto de este artículo. Ciertamente, el régimen de responsabilidad del propietario derivado de la situación del suelo entró en vigor de manera inmediata con la promulgación de la Ley 10/1998, de 21 de abril, de residuos. Ahora bien, la plena efectividad de la obligación de sufragar los costes de descontaminación que recae sobre el propietario requiere que, como se indicó más arriba, el órgano autonómico ambiental haya adoptado previamente la declaración de suelo contaminado. Solo entonces es jurídicamente exigible la obligación de descontaminación. La mayor o menor celeridad en la adopción de esta declaración por el órgano ambiental autonómico dependerá de diversos factores: la situación general de los suelos en cada comunidad autónoma ${ }^{55}$, el número de solicitudes dirigidas a obtener la citada declaración, el nivel y la extensión de los estudios preliminares,

50 Por todas, SSTC 126/1987, de 16 de julio, FJ 11; y 89/2009, de 20 de abril, FJ 3.

51 En materia tributaria o de cotizaciones a la Seguridad Social no rige la prohibición absoluta de retroactividad del art. 9.3 CE, por lo que la protección que dispensa el Tribunal Constitucional se articula a través del principio de seguridad jurídica, reconocido en el mismo precepto constitucional. Véase, entre otras, SSTC 173/1996, de 13 de octubre; 234/2001, de 13 de diciembre; y 89/2009, de 20 de abril.

52 STC 81/2015, de 30 de abril (FJ 8).

53 En la STC 81/2015, de 30 de abril, el Tribunal rechazó que las medidas de contención del gasto público introducidas repentinamente, que incluían recortes de las retribuciones de los funcionarios, fueran absolutamente imprevisibles.

54 Véase la nota 49.

55 Téngase en cuenta que, por ejemplo, en la Comunidad Autónoma del País Vasco, este problema ambiental afectaba a casi el $16,5 \%$ de la superficie útil de la Comunidad 
inventarios e informes sobre la calidad del suelo que se hayan realizado hasta la fecha, las prioridades ambientales que fije el órgano ambiental competente de cada comunidad autónoma y la evolución de las tecnologías aplicables a la descontaminación.

En cualquier caso, desde el punto de vista jurídico debe subrayarse que la obligación de descontaminación no existía de iure a la entrada en vigor de la primera norma estatal que reguló la descontaminación de los suelos: su surgimiento se supeditó a la adopción de dos actos administrativos, la pertinente declaración de suelo contaminado y el posterior requerimiento de descontaminación al sujeto considerado responsable, actuaciones cuya realización pudo y puede - todavía - demorarse mucho en el tiempo. Todo ello opera, en la práctica, como una especie de régimen transitorio, que puede ser prolongado hasta que surta efectos el mandato de saneamiento, periodo en el cual los propietarios pueden tener tiempo para internalizar el coste de la descontaminación $^{56}$. Si el cambio legislativo consistente en la imposición de la carga de descontaminación del suelo a los propietarios no causantes de dicha contaminación hubiera sido exigible de forma inmediata a partir de abril de 1998, esto es, desde el primer día de la entrada en vigor de la primera disposición legal en este sentido, podría quizá hablarse de imprevisibilidad del cambio legislativo. Pero, como se indicó más arriba, la Ley solo definió el deber de saneamiento como carga inherente al contenido del derecho de propiedad, y estableció una serie de trámites previos antes de que fuera efectiva y exigible la obligación de recuperación de la calidad del suelo.

\section{EL DERECHO DE PROPIEDAD}

\subsection{Las medidas de recuperación excesivas}

Por lo general, quien en la actualidad pretende poner en el mercado un suelo declarado contaminado o en el que se ha desarrollado una actividad potencialmente contaminante debe saber que la situación del suelo y la carga legal de descontaminación que arrastra su propiedad incidirán en su valor del mercado. Puede asumirse que, si acomete las medidas de recuperación que se le demandan o si acepta el precio que el mercado le ofrece, ello será

Autónoma en el momento de la aprobación de la Ley vasca 1/2005, de 4 de febrero, para la prevención y corrección de la contaminación del suelo.

56 Para algunos autores que defienden la aplicación del principio de confianza legítima a las modificaciones legislativas que surten efectos de forma inmediata, la protección de la confianza legítima puede consistir, justamente, en la necesidad de prever regímenes transitorios. Véase en este sentido Bacigalupo Saggese (2002: 129). 
normalmente indicativo de que el impacto económico de la obligación de recuperación es, con todo, inferior a la utilidad que le proporcionará en el futuro el suelo o que le reporta ya su enajenación, descontada en su caso la carga tributaria por el incremento del valor de los terrenos. En suma, en tales supuestos se puede considerar que las ventajas que derivan del régimen legal de la propiedad superan a las desventajas que también conlleva, entre las que se incluye la obligación de descontaminación.

Por el contrario, se puede considerar como una situación de especial estrés la del propietario que se enfrenta a unas medidas de recuperación declaradas y exigidas por la Administración de tanto alcance que tiene que dedicar una suma de dinero muy importante — con relación al valor del mercado del propio bien - para cumplir con ellas, hasta el punto de anular de forma total o parcial su valor real; situación que, incluso, puede obligarle a poner en venta el propio bien para poder satisfacer la carga financiera del saneamiento. Por tanto, debe analizarse si una ilimitada obligación de limpieza y descontaminación impuesta al propietario no causante de la contaminación es en estos casos compatible con la Constitución.

La imposición al propietario que no ha originado la contaminación del suelo de la carga de realizar o sufragar su descontaminación constituye — como se dijo - una delimitación del contenido del derecho fundamental de propiedad. El legislador puede «establecer, en el marco de la Constitución, las limitaciones y deberes inherentes a la función social de cada tipo de propiedad ${ }^{57}$. Ahora bien, esos deberes deben establecerse «en el marco de la Constitución». Aceptando que la finalidad de «restaurar el medio ambiente» no solo es constitucionalmente legítima, sino que está expresamente consagrada en el art. 45 $\mathrm{CE}$, la cuestión estriba en si los deberes establecidos respetan el contenido esencial (art. 53.1 CE) y el principio de proporcionalidad que rige para las intervenciones restrictivas en el ámbito de los derechos fundamentales.

El respeto del contenido esencial obliga a que el propietario conserve, tras la correspondiente delimitación, una «utilidad individual»" ${ }^{58}$. La obligación de descontaminación se añade a otras limitaciones propias de la ordenación jurídica del derecho de propiedad. La suma de las limitaciones del derecho de propiedad no puede hacer perder esa utilidad individual. Al propietario no puede privársele de todo el valor de mercado o, al menos, el valor económico

57 STC 37/1987, de 26 de marzo, FJ 9.

58 STC 37/1987, de 26 de marzo, FJ 2. Doctrina reiterada, entre otras, en SSTC 170/1989, de 19 de octubre, FJ 8 b); 204/2004, de 18 de noviembre, FJ 5; y 141/2014, de 11 de septiembre, FJ 9 b). 
de la $\operatorname{cosa}^{59}$. Como ha señalado Baño León, «el mero hecho de poseer por cualquier título un terreno no justifica la exigencia de atender una obligación económica pública que supera con mucho al valor actual que aquel tiene en el mercado " ${ }^{60}$. En el mismo sentido, otros autores sitúan también el límite infranqueable para el legislador en el valor del suelo ${ }^{61}$. Al mismo supuesto se equiparan también, según Baño León, «aquellos casos en los que los costes, aun sin superar el valor de mercado del suelo, impongan sacrificios irrazonables o desproporcionados». En ambas hipótesis, se infringiría el contenido esencial del derecho de propiedad ${ }^{62}$.

59 Ciertamente, la doctrina del Tribunal Constitucional excluye el valor de mercado como directriz constitucional de la indemnización garantizada por el art. 33.3 CE, y se orienta según el valor económico [SSTC 166/1986, de 19 de diciembre, FJ 13; 141/2014, de 11 de septiembre, FJ 9 b); y 218/2015, de 22 de octubre, FJ 5]. Y con respecto al legislador, véase J. M. Baño León (2007), «Las valoraciones del suelo», en Revista General de Derecho Administrativo, 15. Ese rechazo del Tribunal Constitucional al valor de mercado no le vincula al legislador, que puede configurar la indemnización en torno al valor de mercado. Ahora bien, no está claro si ese rechazo del Tribunal Constitucional al valor de mercado rige también a la hora de ponderar la función social de la propiedad ex art. 33.2 CE. Si, en esa ponderación, la función social de la propiedad se contrasta con el beneficio que el propietario puede obtener en el mercado, esa función social podrá definirse con más amplitud; si, por el contrario, se contrasta con un valor económico, la función social tendrá que constreñirse correlativamente, so pena de ahogar la utilidad individual. Probablemente no cabe una respuesta unívoca. Así, los procedimientos expropiatorios y las actuaciones urbanísticas en régimen de equidistribución se ubican en el ámbito del art. 33.3 CE (directamente o por vía analógica), por lo que el valor de contraste para determinar el carácter excesivo o no de las medidas de recuperación impuestas al propietario deberá ser necesariamente el valor económico del bien, que es el que se le garantiza constitucionalmente al propietario mediante la indemnización prevista en el art. 33.3 CE.

60 Baño León (2002: 48).

61 De Miguel Perales (2007: 111); y De la Varga Pastor (2012; 306, 467), para quien sería inconstitucional por lo menos lo que rebase del valor del suelo, aunque admite rebasamiento cuando el propietario haya sacado provecho de la situación o lo haya hecho de mala fe.

Baño León (2002: 48). En el derecho norteamericano se habla a este respecto de «regulatory takings», es decir, de leyes que, al delimitar el contenido de la propiedad, van «demasiado lejos» y representan materialmente una expropiación: véase, al respecto, M. Aguilera Vaqués (2008), «Propuestas para definir los límites constitucionales a la regulación de la propiedad privada (regulatory takings v. regulaciones inconstitucionales de la propiedad)", en Estudios sobre la Constitución Española - Homenaje al Profesor Jordi Solé Tura, vol. II, Madrid: Cortes Generales, págs. 939-964. 
Más allá de la prohibición de superar el valor económico o de mercado, resulta difícil precisar en abstracto qué sacrificios resultan irrazonables o desproporcionados, esto es, determinar el límite del sacrificio del derecho compatible con la Constitución (la llamada Opfergrenze). La propia normativa básica dispone que solo pueden imponerse tareas de limpieza que tengan costes razonables ${ }^{63}$. Este mandato normativo significa que deberá haber una relación equilibrada entre el coste de la descontaminación y la utilidad de la medida de descontaminación, esto es, la mejora de la calidad del suelo. Pero este límite externo y básicamente económico (en cuanto que solo atiende al empleo eficiente de los recursos disponibles) no es suficiente para garantizar plenamente el respeto del contenido esencial del derecho de propiedad, pues las medidas de descontaminación exigidas al propietario pueden ser útiles y tener un coste razonable para el resultado perseguido, pero no preservar una utilidad económica suficiente del bien para el propietario. Como no parece posible ni recomendable que se fijen proporciones precisas por vía legislativa, lo más adecuado sería dejar en manos de la Administración, primero, y de los jueces, después, la decisión sobre el carácter razonable de las exigencias de descontaminación en cada caso concreto. En principio, cabe entender que se preserva la utilidad mínima inherente al derecho de propiedad si el coste de la descontaminación no supone una parte considerable del valor de mercado del bien después de la descontaminación.

El Tribunal Constitucional Federal alemán se pronunció en una sentencia de 16 de febrero de 2000 (1 BvR 242/91 y 315/99) sobre la constitucionalidad del sistema previsto en Alemania ${ }^{64}$. Antes de analizar la sentencia, debe subrayarse que el alcance de la responsabilidad del propietario en Alemania es mucho más reducido que en Espańa. Por un lado, el régimen legal se aplica a la limpieza de la contaminación del suelo que se haya producido con posterioridad al 1 de marzo de 1999, y siempre que ello resulte proporcionado a la contaminación preexistente ${ }^{65}$. Por otro lado, se protege la confianza legítima del propietario que adquirió el suelo sin conocer su situación alterada o contaminada; el propietario anterior que hubiera transmitido el suelo con posterioridad al 1 de marzo de 1999 solo responde si conocía o debiera haber conocido la situación del suelo ${ }^{66}$. Pues bien, incluso con esas amplias limitaciones legales, el Tribunal Constitucional Federal alemán no descartó problemas de consti-

\footnotetext{
63 Art. 7.4 del Real Decreto 9/2005.

64 La sentencia ha sido comentada por H. Mohr (2003), "Zur Begrenzung der Zustandshaftung bei Altlasten», Neue Zeitschrift für Verwaltungsrecht, 6, págs. 686-688. Para un análisis en castellano de la sentencia véase De la Varga Pastor (2012: 453-464).

65 Parágrafo 4, apdo. 5, de la Bundes-Bodenschutzgesetz de 17 de marzo de 1998, en la versión de la última modificación introducida el 31 de agosto de 2015.

66 Parágrafo 4, apdo. 6, ibid.
} 
tucionalidad en una aplicación mecánica del régimen legalmente previsto y obligó a las autoridades administrativas y judiciales a ponderar diversas circunstancias, que se exponen a continuación:

a) El legislador tiene que establecer una relación equilibrada entre los intereses dignos de protección de los afectados, así como respetar todas las disposiciones constitucionales: «En particular está vinculado al principio constitucional de proporcionalidad y al principio de igualdad del art. 3.1 de la Ley Fundamental. La libertad de configuración del legislador no es idéntica para todos los ámbitos. En la medida en que la propiedad garantiza la libertad personal del individuo en el ámbito patrimonial, disfruta de una protección especial».

b) La responsabilidad por la situación del suelo halla su fundamento en el dominio que la propiedad lleva aparejado, así como en la conexión entre las ventajas y las cargas de la cosa. De la misma manera que al propietario le corresponden, según el derecho vigente, las ventajas del uso privado de la cosa, incluso cuando aparecen sin su intervención, también debe soportar las cargas de la cosa cuando él no ha causado el riesgo.

c) Aunque la responsabilidad del propietario por la situación del suelo no es en sí incompatible con la Constitución, debe mantenerse en el nivel de lo que pueda exigirse al propietario para la defensa frente al riesgo. Una importancia especial cobra aquí el principio de proporcionalidad, que solo permite aquellas restricciones del derecho fundamental que sean idóneas e indispensables de cara a la finalidad perseguida. En el marco del juicio de proporcionalidad debe ponderarse la carga impuesta al propietario responsable de la situación del suelo, por un lado, y la relevancia para el interés general, por otro. Entre otras consideraciones a tener en cuenta, se ofrecen — siempre según el Alto Tribunal alemán— las siguientes:

- Puede servir como criterio la relación entre la carga financiera y el valor de mercado de la cosa después del saneamiento del suelo, por ejemplo si el valor del bien se eleva debido al mercado o al planeamiento urbanístico. El propietario no tiene que venir obligado a enajenar el bien para poder cubrir los costes del saneamiento. Ahora bien, el valor de mercado no representa más que un criterio, pues el interés individual del propietario en el bien inmueble puede ser mayor que su valor de mercado.

- Una carga que supere esos límites puede no ser exigible si el riesgo que se vincula al bien ha sido causado por sucesos naturales, por causas generales atribuibles a la generalidad o por terceros no autorizados a utilizar el bien. 
- Asimismo no es exigible una carga que eleve los gastos de descontaminación hasta el valor de mercado si el suelo que debe recuperarse constituye la parte esencial del patrimonio del obligado y el fundamento de su vida privada, incluido el de su familia.

- Puede imponerse, no obstante, un coste de descontaminación superior al valor de mercado del suelo si el propietario ha asumido conscientemente el riesgo del peligro surgido: por ejemplo, al adquirir el bien conociendo el carácter contaminado del suelo ocasionado por anteriores propietarios o poseedores, o al haber autorizado ese uso.

- La responsabilidad del patrimonio no es ilimitada por el hecho de que el propietario tenga suficiente capacidad económica para afrontarla.

d) En la medida en que el legislador, que debe regular el contenido y los límites del derecho de propiedad de acuerdo con el art. 14.1 de la Ley Fundamental, no haya regulado expresamente los límites de la responsabilidad por la situación del suelo, las autoridades y los tribunales tienen que garantizar, mediante la interpretación y la aplicación de las disposiciones que fundamentan la responsabilidad y la obligación de recuperación, que la carga del propietario no exceda la medida de lo exigible con arreglo al art. 14, apdo. 1, segundo inciso, y apdo. 2, de la Ley Fundamental.

Hasta la fecha, el Tribunal Constitucional español no se ha pronunciado sobre los límites constitucionales de las obligaciones de descontaminación impuestas a los propietarios, pero no se aprecia razón alguna por la que los criterios expuestos no pudieran ser acogidos también — si llegara el asunto a su conocimiento- por el Tribunal Constitucional español, ni aplicados por cualquier juez español ${ }^{67}$.

En una Sentencia de 4 de marzo de 2015, el Tribunal de Justicia de la Unión Europea, en respuesta a una cuestión prejudicial italiana, afirmó que la Directiva 2004/35/CE sobre responsabilidad ambiental (que incluye los principios de que quien contamina, paga, de cautela y de corrección de los atentados al medioambiente) «no se opone a una normativa nacional como la controvertida en el litigio principal, que, cuando es imposible identificar al responsable de la contaminación de un terreno u obtener de este las medidas reparadoras, no permite a la autoridad competente imponer la ejecución

67 En el mismo sentido, Baño León (2002: 49). 
de las medidas preventivas y reparadoras al propietario de dicho terreno, no responsable de la contaminación, al que se exige únicamente reembolsar los gastos relativos a las actuaciones realizadas por la autoridad competente por un importe no superior al valor de mercado del paraje, determinado una vez ejecutadas esas actuaciones» ${ }^{68}$. Por tanto, la existencia de límites constitucionales a la obligación de corrección de la contaminación del suelo no infringe el derecho de la Unión ${ }^{69}$.

3.2. La obligación de descontaminación que se yuxtapone a la privación de la propiedad: el caso de los procesos urbanísticos de equidistribución

Si no hay actuación urbanística de por medio, la Administración goza de una amplia discrecionalidad, tanto para efectuar la declaración de suelo contaminado y determinar su contenido, cuanto para decidir cuándo requerir su descontaminación efectiva al sujeto responsable, en función de las características del suelo (grado de contaminación, uso del suelo, ubicación, etc.) y sus propias prioridades, establecidas de acuerdo con su política ambiental. No obstante, cuando se proyecta una actuación urbanística, la descontaminación se contempla de otra forma. La integración de la tarea de descontaminación del suelo dentro del proceso de urbanización no es solo la solución más operativa, especialmente si se conoce de antemano que en el ámbito de la actuación urbanística existen o han existido focos de contaminación ${ }^{70}$, sino también la única opción respetuosa con los intereses en juego ${ }^{71}$. En consecuencia, la

68 STJ de 4 de marzo de 2015, Fipa Group y otros, as. C-534/13, apdo. 63 y fallo.

69 Álvarez Lata (2016: 4-5) sostiene que el pronunciamiento del TJUE recogido en el texto no excluiría el mantenimiento de una regla más rigurosa como la que existiría en derecho español. En mi opinión, la regla que establece el derecho español debe interpretarse de acuerdo con el art. $33 \mathrm{CE}$ : una obligación del propietario que anulara el valor de mercado del suelo una vez descontaminado infringiría el contenido esencial del derecho de propiedad privada.

70 J. A. Loste Madoz (2015), «El medio ambiente y la empresa. Régimen jurídico de los suelos contaminados», en A. Serrano Acitores (dir.), La intervención administrativa y económica en la actividad empresarial, Barcelona: Bosch, pág. 928.

71 En Alemania, la práctica de los municipios, en el siglo pasado, de reclasificar como uso residencial los suelos anteriormente utilizados para usos industriales, vertederos y similares, sin incorporar la descontaminación del suelo en el planeamiento urbanístico, condujo a importantes problemas de desarrollo de los planeamientos. La cuestión de si los afectados podían exigir a las autoridades locales una reparación por las inversiones realizadas ocupó a la doctrina y la jurisprudencia de los años 90 del siglo pasado. Finalmente, el Tribunal Supremo declaró que la legislación alemana permitía a 
descontaminación de los concretos suelos incluidos en la actuación urbanística se convierte en una prioridad ligada a la ejecución del planeamiento. De hecho, la normativa urbanística parece tener dos únicas preocupaciones: por un lado, evitar la repercusión de los costes de descontaminación al conjunto de la comunidad reparcelatoria; y, por otro lado, impedir una situación de paralización de la actuación urbanística que pueda provenir de la falta de limpieza del suelo contaminado ${ }^{72}$. Por otro lado, a menudo la finalidad de la actuación urbanística es dotar al suelo de un nuevo uso, lo que en ocasiones puede acarrear unas exigencias de descontaminación superiores a las del uso anterior. En suma, todos estos aspectos deben ser tenidos en cuenta a la hora de diseñar un sistema jurídico-público adecuado de restauración de los suelos contaminados.

La consideración del coste de descontaminación como obligación extraurbanística, esto es, que no forma parte del conjunto de obligaciones que asumen los propietarios como consecuencia del deber de urbanización, necesita ser revisada ${ }^{73}$ : la obligación de saneamiento no es una carga real que pesa sobre el suelo contaminado, sino una responsabilidad del causante o del titular dominical, aquel por su conducta y este por su condición de propietario; y si la comunidad reparcelatoria no es la causante de la contaminación, también puede no serlo el propietario del suelo, sin que haya justificación para aplicar un rasero distinto a una y a otro ${ }^{74}$. En los supuestos de contaminación histórica y difusa no existe posibilidad real para el propietario de repetir los costes de descontaminación contra el causante de la contaminación.

Además, desde la perspectiva constitucional no es irrelevante la superposición en el tiempo de dos injerencias en el contenido del derecho de propiedad privada: por un lado, la derivada de la obligación de descontaminación;

quienes iban a residir en las zonas sujetas a planeamiento reclamar una reparación. Véase, al respecto, B. Kümper (2015), «Unionsrechtliche Wiederkehr der AltlastenFälle: zur Staatshaftung wegen mangelnder Umweltprüfungen», en Deutsches Verwaltungsblatt, 14, págs. 870-871.

72 Loste Madoz (2015: 927-928). Para el autor, se trata de un mecanismo que permite «una primera asignación de los costes de saneamiento de los terrenos, a efectos de que el proceso urbanizador no quede en una situación de bloqueo mientras se determinan las responsabilidades ambientales», pues no impide que el propietario actual del suelo pueda ulteriormente repercutir los costes que haya afrontado contra el causante de la contaminación.

73 A favor de la consideración del coste de descontaminación como «carga de urbanización especial» por su carácter extraurbanístico: Laso Martínez (2007: 2365); Loste Madoz (2011); en contra, Pérez Dapena y Picó Barandiarán (2011: 120, 132-133).

74 Pérez Dapena y Picó Barandiarán (2011: 133). 
por otro lado, la privación singular del bien (caso de la expropiación) o la sujeción a la función pública urbanizadora que puede desencadenar también una privación del bien. Sin duda se trata de restricciones independientes una de otra, con su propia justificación (ambiental en un caso, urbanística o de utilidad pública en el otro), que en la práctica se pueden solapar: en el proceso urbanístico de equidistribución se exige al propietario la descontaminación del suelo que aporta o se le descuenta su coste del saldo de la cuenta de liquidación del proyecto. Si el propietario al que se le exige la descontaminación del suelo o se le repercute el coste que ello suponga no recibe la futura utilidad porque, debido a circunstancias ajenas a su voluntad, no continua en la titularidad del bien, como ocurre en las actuaciones expropiatorias y puede ocurrir en las urbanísticas ${ }^{75}$, no es posible compensar idealmente el coste actual de la

75 La legislación vigente ya diferencia, en lo tocante a la valoración del suelo en el régimen de equidistribución de beneficios y cargas, entre la situación del propietario que participa en el proceso urbanizador y la del que queda excluido de dicho proceso por circunstancias ajenas a su voluntad. De acuerdo con el art. 40.2 del Real Decreto Legislativo 7/2015, de 30 de octubre, por el que se aprueba el texto refundido de la Ley de Suelo y Rehabilitación Urbana, "[e]n el caso de propietarios que no puedan participar en la adjudicación de parcelas resultantes de una actuación de urbanización por causa de la insuficiencia de su aportación, el suelo se tasará por el valor que le correspondería si estuviera terminada la actuación, descontados los gastos de urbanización correspondientes incrementados por la tasa libre de riesgo y la prima de riesgo». La norma, que procede del art. 26.2 de la Ley 8/2007, de 28 de mayo, de suelo, persigue evitar el enriquecimiento sin causa del urbanizador, sea el Ayuntamiento, la Junta de Compensación o el agente urbanizador. En efecto, según la doctrina, «[d] e este modo la ley distingue entre el propietario que voluntariamente no quiere participar en la actuación, cuyo suelo debe valorarse como rural, y el propietario que forzosamente queda excluido de la urbanización, supuesto en que por razones derivadas del principio de igualdad de trato y del de enriquecimiento sin causa se reconoce al propietario que queda excluido o limitado en su derecho la misma plusvalía que al resto de propietarios, como es lógico deducidos los gastos y el valor del riesgo en que no incurre» [Baño León (2007: 14)]. En suma, la legislación vigente tiene en cuenta que el urbanizador puede ser el beneficiario de la plusvalía urbanística que se niega al propietario por circunstancias ajenas a su voluntad. A mi juicio, quien renuncia a participar en la actuación urbanística por el carácter elevado de los gastos de urbanización estimados lo hace también por circunstancias ajenas a su voluntad. En cualquier caso, lo que aquí se argumenta es que el urbanizador es siempre el beneficiario de la utilidad económica resultante de la ejecución de la obligación de descontaminación impuesta al propietario y que, por tanto, la legislación, a la vista de esa transferencia del beneficio resultante, debería trasladar la carga de la descontaminación al urbanizador, con independencia de que el propietario participe o no en la actuación urbanística; pues, 
descontaminación con la utilidad futura que reporte el bien, ni con el eventual incremento del valor del bien (ya sea debido a la labor de descontaminación, ya sea por la propia actuación urbanística en su conjunto $)^{76}$. En consecuencia, resulta desproporcionado imponerle una doble restricción al propietario que ni ha obtenido beneficio alguno del perjuicio ambiental causado al suelo ni lo va a obtener de la futura situación ambiental y urbanística del suelo: la doble restricción consiste en sufragar el coste de la descontaminación del suelo y, al mismo tiempo, padecer la privación singular de la titularidad dominical sobre el suelo. En esta situación, la imposición de la obligación de descontaminación al propietario que no participa en la actuación urbanística y que dejará de ser propietario a corto plazo no constituye una medida indispensable para alcanzar el fin perseguido por la norma ambiental.

Incluso si el propietario participa en la actuación urbanística y resulta adjudicatario de una parcela en el ámbito de actuación, la conclusión debería ser similar. Quien se beneficia de la exigibilidad en el proceso urbanístico, de la obligación de descontaminación es quien, tras la actuación urbanística, obtiene suelo limpio con el derecho a usarlo y a edificar sobre él de acuerdo con la Ley. Por tanto, siguiendo los adagios ibi emolumentum ibi onus y commodo farens incommoda et onera sustinere debet, quien debería asumir la carga de la descontaminación es quien se beneficie de la futura utilidad del bien como consecuencia de la actuación expropiatoria o urbanística: el beneficiario de la expropiación o los propietarios de las fincas resultantes de la actuación urbanística, respectivamente.

Según la normativa básica, la declaración de suelo contaminado atiende a la "naturaleza y los usos» del suelo y las actuaciones de descontaminación se modulan «en función de los diferentes usos» ${ }^{77}$. Esa modulación

de lo contrario, se produciría un trasvase no justificado de los beneficios económicos resultantes de la descontaminación de un particular (el propietario de la finca aportada) a otro (el promotor de la actuación urbanística).

76 Es el propio legislador básico el que relaciona las operaciones de descontaminación con «posibles plusvalías que adquieran los suelos». Así, el art. 36.4 de la Ley 22/2011 dispone que "[s]i las operaciones de descontaminación y recuperación de suelos contaminados fueran a realizarse con financiación pública, solo se podrán recibir ayudas previo compromiso de que las posibles plusvalías que adquieran los suelos revertirán en la cuantía subvencionada en favor de la Administración pública que haya financiado las citadas ayudas».

77 Arts. 34.1 LRSC y 7.5 del Real Decreto 9/2005, respectivamente. También la acción de regreso que el responsable subsidiario puede en teoría ejercer contra el causante de la contaminación queda limitada al nivel de contaminación asociado al uso del suelo en el momento en el que se produjo la contaminación por el causante (art. 36.2 
no es irrazonable, pero igualmente la ley debería prever que el coste de las correspondientes medidas de recuperación, que serán más o menos importantes dependiendo del nuevo uso, recaiga en quienes se benefician de ese futuro uso. La normativa catalana ha introducido una limitación a este respecto: «[...] los causantes de la contaminación de un emplazamiento están obligados a sanearlo en función del uso urbanístico que tenía cuando lo transmitieron. No pueden requerirse medidas de saneamiento complementarias vinculadas a los nuevos usos urbanísticos del suelo, salvo que hayan sido promovidas por ellos mismos» ${ }^{78}$. Cuando menos, el mismo criterio debería aplicarse a los propietarios no causantes de la contaminación.

Por tanto, no solo para superar las dudas de inconstitucionalidad expuestas en el texto, sino también en aras de un mejor sistema de imputación de la obligación de saneamiento de los suelos, de lege ferenda, se propone aquí que, cuando el propietario no sea el causante de la contaminación, en los procesos urbanísticos de equidistribución, la descontaminación se incorpore a los demás deberes inherentes a la actuación de urbanización y que, en los procesos expropiatorios, el coste de la descontaminación del suelo declarado contaminado se excluya de la fijación del justiprecio. Con mayor razón, si cabe, si el propietario hubiese adquirido la propiedad antes de la entrada en vigor de la Ley 10/1998 o, a más tardar, antes de la entrada en vigor del Real Decreto 1/2005 que desarrolló la publicidad inmobiliaria.

\section{CONCLUSIONES}

En este trabajo no se cuestiona la validez del principio medioambiental de que quien contamina debe asumir las consecuencias lesivas de su actividad para los bienes y derechos de terceros. La situación analizada no es la del causante de la contaminación, sino la del propietario al que se le exige la recuperación de un suelo que él no contribuyó por acción u omisión a contaminar, y cuyo estado no podía conocer en el momento de la adquisición. La legislación vigente proclama taxativamente su responsabilidad subsidiaria en el caso de no poder identificar al causante de la contaminación o no poder proceder contra él.

LRSC). De esta norma se infiere que la responsabilidad del propietario está limitada a la descontaminación exigida para el uso que da al suelo.

78 Art. 15 de la Ley 9/2008, de 10 de julio, de modificación de la Ley 6/1993, de 15 de julio, reguladora de los residuos. Criterio propuesto anteriormente por Loste Madoz (2007: 161). 
El título de propiedad es un nexo suficiente para responder de los efectos de la contaminación existente en un emplazamiento y quedar obligado a la limpieza del suelo. La imposición al propietario que no ha originado la contaminación del suelo de la carga de realizar o sufragar su descontaminación constituye una restricción legal en el contenido del derecho fundamental de propiedad. Esa restricción se fundamenta en la función social de la propiedad, a la que se le puede imponer la carga de restaurar el suelo contaminado hasta niveles aceptables para la salud humana y el medio ambiente, de acuerdo con el uso al que se destina el bien. Ahora bien, aunque se persiga una finalidad constitucionalmente legítima, se deben respetar el contenido esencial y el principio de proporcionalidad.

El respeto del contenido esencial requiere que el propietario preserve una utilidad mínima. Esa utilidad mínima se puede considerar preservada si el coste de la descontaminación no supone una parte considerable del valor de mercado del bien o, aunque suponga una parte considerable, queda absorbido por el previsible incremento de valor de mercado tras su descontaminación. En esta línea apunta la Sentencia del Tribunal Constitucional Federal alemán de 16 de febrero de 2000, que elabora magistralmente los límites que derivan del derecho fundamental a la propiedad privada, y que debería constituir una pauta interpretativa relevante tanto para el Tribunal Constitucional espańol cuanto para el juez español.

El problema se complica cuando se superponen en el tiempo dos restricciones al contenido del derecho de propiedad privada: la derivada de la obligación de descontaminación; y la privación singular del bien (caso de la expropiación) o la sujeción a la función pública urbanizadora que puede desencadenar también una privación singular del bien. Si el propietario al que se le exige la descontaminación del suelo o el coste que ello suponga no puede obtener la futura utilidad porque no continua en la titularidad del bien, como ocurre en las actuaciones expropiatorias y puede ocurrir en los procesos de equidistribución, no es posible compensar idealmente el coste actual de la descontaminación con la utilidad futura que le reporte el bien, ni con el eventual beneficio resultante del incremento del valor del bien. Quien debería asumir la carga de la contaminación es, a juicio del autor de este artículo, quien se beneficie del uso al que se destina el bien como consecuencia de la actuación expropiatoria o urbanística: el promotor de la actuación urbanística (esto es, los propietarios de las fincas resultantes) o el beneficiario de la expropiación. 